Journal of the Society for the Study of Architecture in Canada Le Journal de la Société pour l'étude de l'architecture au Canada

\title{
Vines, Gates, and Temples: Using Cemeteries to Understand Mormonism in Canada
}

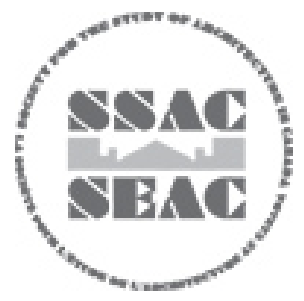

\section{Brooke Kathleen Brassard}

Volume 43, numéro 1, 2018

Religious Architecture in Canada

URI : https://id.erudit.org/iderudit/1049409ar

DOI : https://doi.org/10.7202/1049409ar

Aller au sommaire du numéro

Éditeur(s)

SSAC-SEAC

ISSN

2563-8696 (numérique)

Découvrir la revue

Citer cet article

Brassard, B. K. (2018). Vines, Gates, and Temples: Using Cemeteries to

Understand Mormonism in Canada. Journal of the Society for the Study of

Architecture in Canada / Le Journal de la Société pour l'étude de l'architecture au

Canada, 43(1), 65-73. https://doi.org/10.7202/1049409ar 


\section{VINES, GATES, AND TEMPLES: USING CEMETERIES TO UNDERSTAND MORMONISM IN CANADA}

\begin{abstract}
BROOKE KATHLEEN BRASSARD completed her
Ph.D. in the Department of Religious Studies

at the University of Waterloo. Her dissertation

is titled "Thirsty Land into Springs of Water:

Negotiating a Place in Canada as Latter-day

Saints, 1887-1947." She completed her B.A.

in art history/religious studies and M.A. in art

history at the University of Victoria. Her research

interests include new religious movements,

history of religion, Canadian history, and material

and visual culture. When she is not teaching or

writing, she works as the historian for the Rockton

Agricultural Society and as a library clerk for

Musagetes Architecture Library.
\end{abstract}

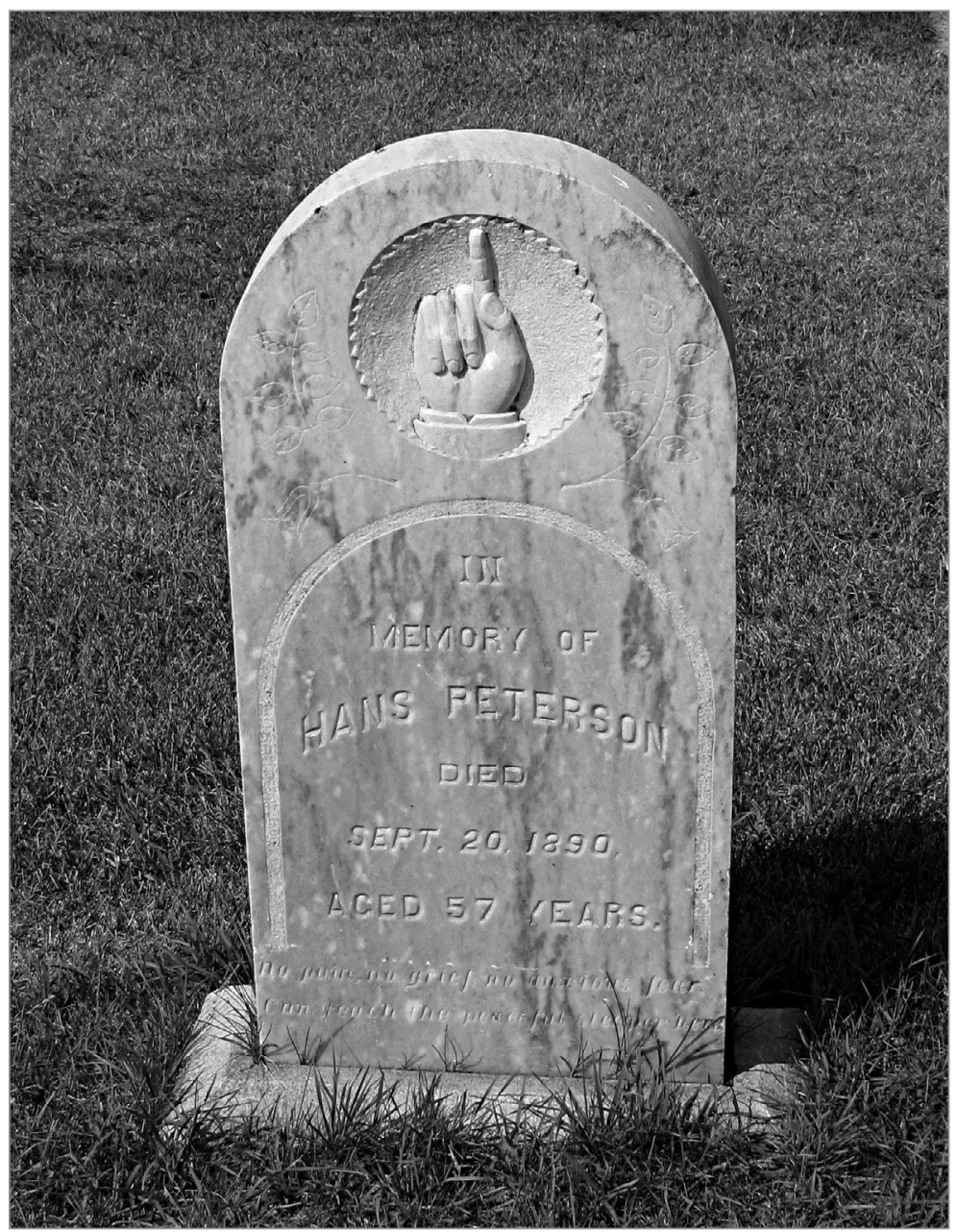

FIG. 1. HANS PETERSON'S GRAVE MARKER, CARDSTON CEMETERY. | BROOKE KATHLEEN BRASSARD.

\author{
>BROOKE KATHLEEN \\ BRASSARD
}

$S_{\mathrm{p}}^{\mathrm{e}}$ everal Latter-day Saints predicted the presence of a Mormon temple from the start of Mormon migration into the District of Alberta, North-West Territories, Canada, in the late nineteenth century. Jonathan Layne [1835-1899], one of the earliest Mormon settlers, prophesied that Canada would provide for the Latter-day Saints (LDS) just as Cache County, Utah, did, and that the country would eventually house their temples. ' On his visit to the new Canadian community in 1888 , John W. Taylor [1858-1916] made a similar forecast: "I now speak by the power of prophecy and say that upon this very spot shall be erected a temple to the name of Israel's God and nations shall come from far and near and praise His high and holy name." 2

These predictions clashed with the expectation that their stay in the NorthWest Territories was temporary, that it was only until they could legally practice plural marriage in Utah that the LDS would remain in Canada. However, a temple symbolized permanence as it was a significant commitment and undertaking for the emerging Canadian LDS communities.

The religious and geographic landscapes of southern, rural Alberta offer a particular lens to view and understand the experiences of Canadian Latter-day Saints. Specifically, permanent sacred spaces, such as the cemetery, possess a wealth of information about the inhabitants and provide evidence of a process of integration into Canadian society. According to folklorists Austin and Alta Fife, cemetery visitors learn 


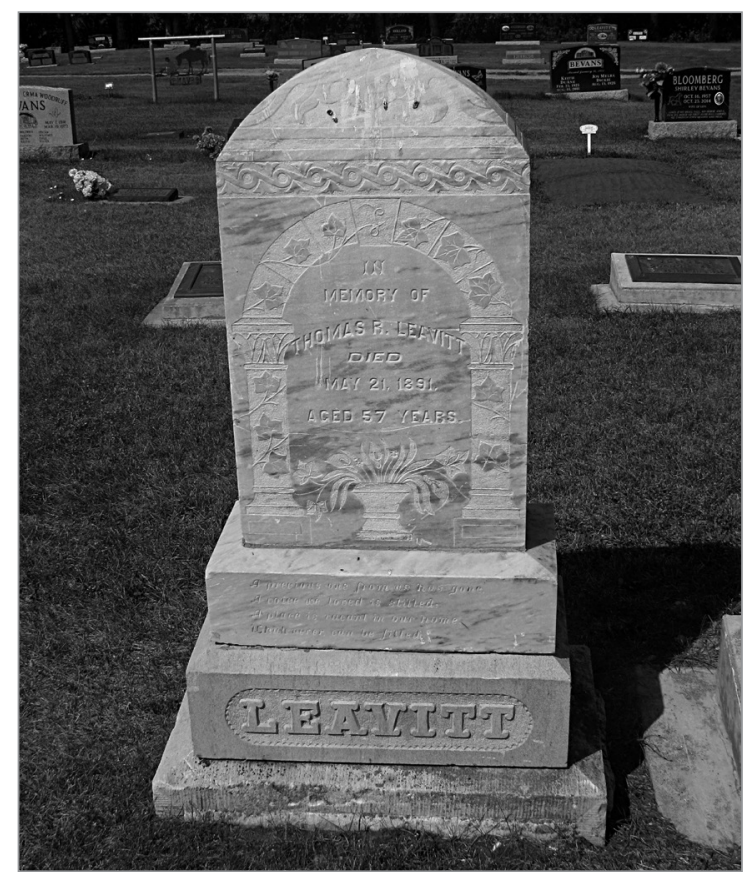

FIG. 2. HANS PETERSON'S GRAVE MARKER, CARDSTON CEMETERY. | BROOKE KATHLEEN BRASSARD.

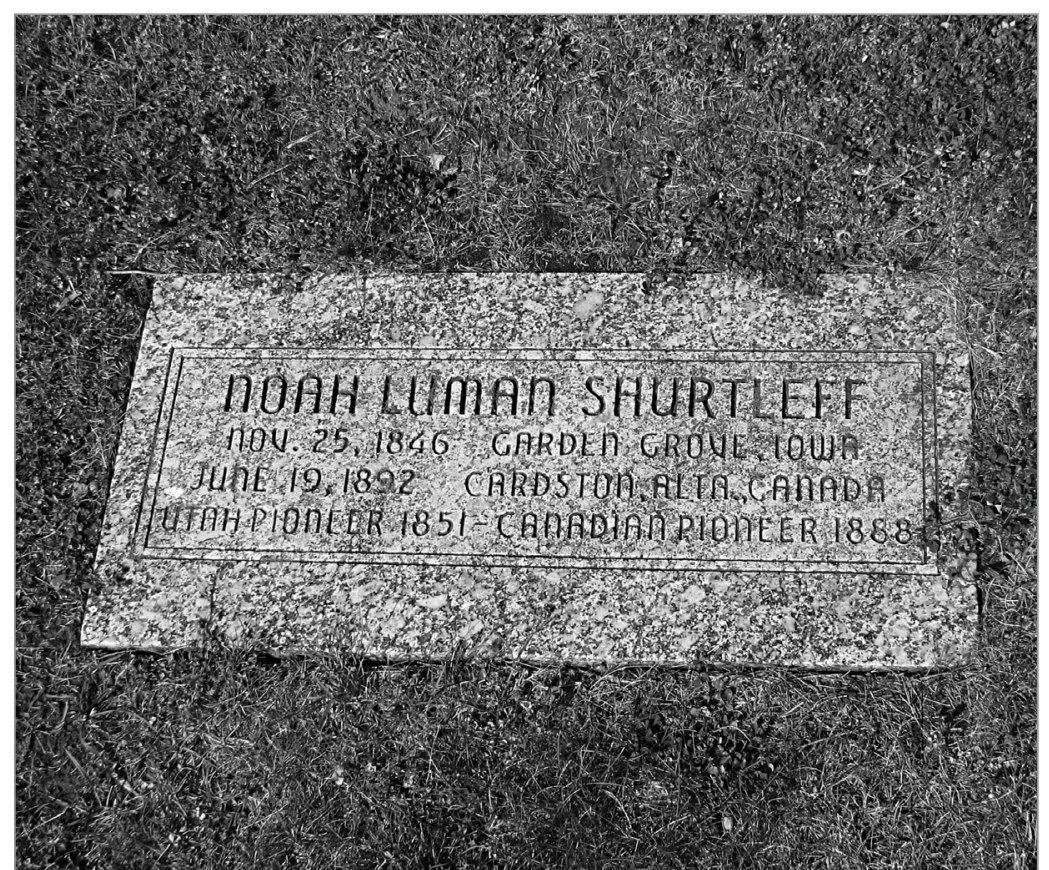

FIG. 3. NOAH SHURTLEFF'S GRAVE MARKER, CARDSTON CEMETERY. | BROOKE KATHLEEN BRASSARD. about their loved ones' "civic pride; their family groups or clans and the individual members thereof; their professions, trades, occupations, and affiliations; the ethnic groups to which they belonged; the fraternal orders of which they were members; terms of military service; disasters and tragedies they experienced." ${ }^{\prime 3}$ Folklorist Carol Edison, studying Utahn graves, agreed: "Gravestones, with their visual symbolism and wealth of cultural information, represent a category of expression offering another way to recognize and understand this unique cultural region." ${ }^{14}$ Writing about rural cemeteries in the Great Plains, professors of architecture Steve C. Martens and Nancy Volkman described the sacred sites as "familiar, ritual landscapes that serve a fundamental human need for remembrance, commemoration, and spiritual healing." ${ }^{5}$ Within the cemetery, the grave marker "is an important way for us to tell the next generation who we were and to help preserve our collective cultural identity. ${ }^{16}$
Like sacred architecture, the cemetery is "a physical space and a spiritual place," but it is the cemetery, according to Elizabethada Wright, an expert on the rhetoric of memorial place, that "confuses the symbolic and physical to allow memories forgotten in other locations to survive-often silently." ${ }^{17}$

In this article, I focus on the material culture of death and memory, but I conducted for my Ph.D. research a larger study examining, in addition to material culture, politics, economics, gendered roles, and marriage practices, and found out that the Mormon experience in southern Alberta was a negotiation between assimilation and peculiarity. ${ }^{8}$ Mainstream Canadian society forced the newcomers to decide what they were willing to give up, maintain, or innovate in their own traditions as well as what they would embrace, reject, or ignore in their adopted society. Certain beliefs, traditions, and practices unique to Mormonism - characteristics that drew borders around themselves and maintained an identity of peculiarity-provided enough tensions between the LDS and outsiders to keep them separate and different. LDS memorials offer evidence of assimilation, negotiation, and tension with mainstream society and present the process of adjusting to a new social environment. Data collected from six cemeteries in southern Alberta revealed three themes: generic Christianity, Mormon symbolism, and temple imagery. The progression from generic symbolism to specific LDS imagery demonstrates how LDS expressions of memorial and death changed as their status and reputation in Canada improved.

\section{GENERIC CHRISTIANITY}

The memorials for the first immigrants did not present anything unexpected for the Late-Victorian era. For example, the headstones of Hans Peterson [1834-1890] 


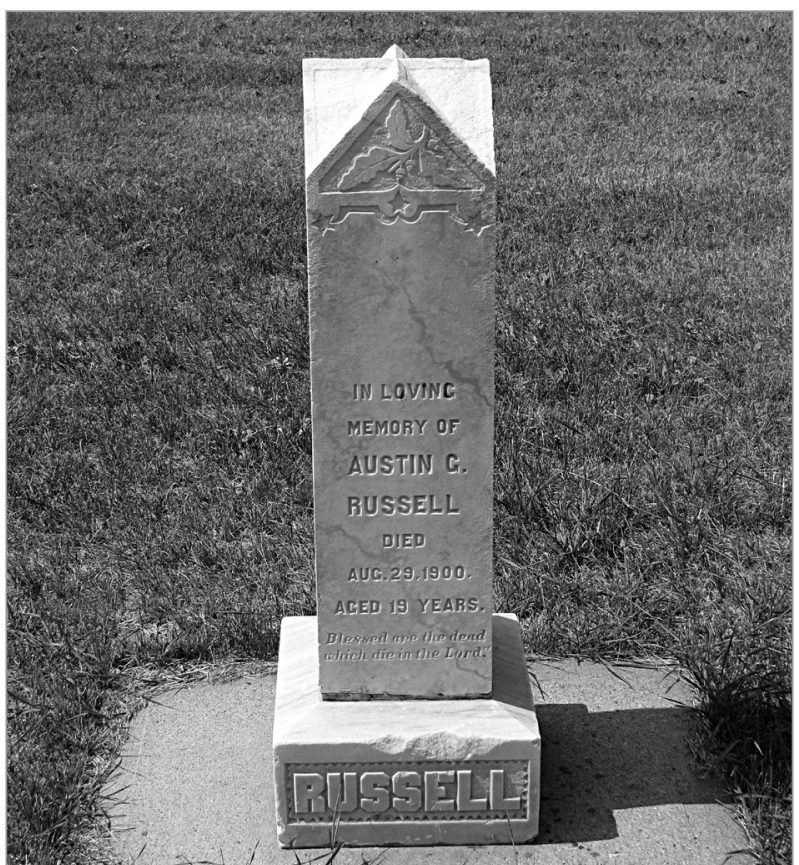

FIG. 4. AUSTIN G. RUSSELL'S GRAVE MARKER, STIRLING CEMETERY. | BROOKE KATHLEEN BRASSARD.

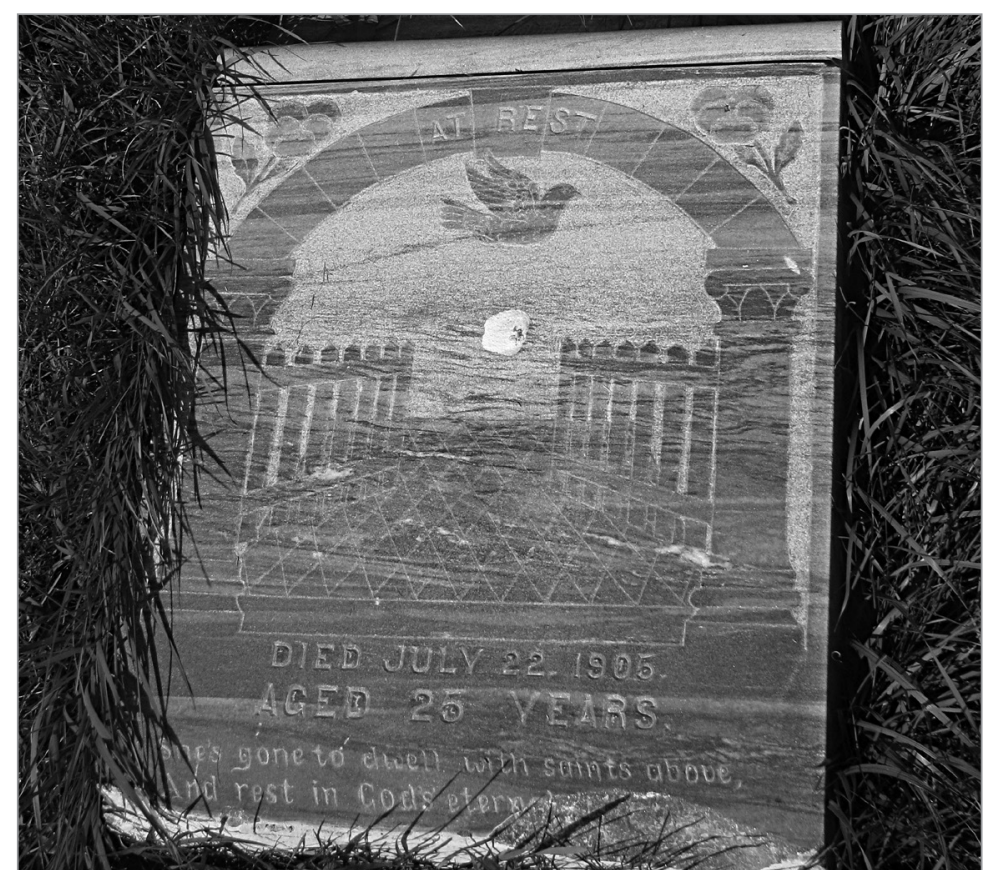

FIG. 5. FANNY CALDWELL'S GRAVE MARKER, CARDSTON CEMETERY. | BROOKE KATHLEN BRASSARD. and Martha Woodward [1863-1894] were stone tablets supported by low platforms. Both depicted a hand pointing an index finger toward the sky, which several scholars have interpreted as indicative of the destination of the deceased: heaven (fig. 1). ${ }^{9}$ In addition to this common Christian symbol, Peterson's headstone included the also familiar epitaph: "No pain, no grief, no anxious fear can reach the peaceful sleeper here."10 Peterson was a shoemaker, born in Denmark but immigrated to Utah in 1870 where he took a plural wife. After serving a prison sentence for polygamy, Peterson and his second wife Jennie moved to Alberta. Woodward was a thirty-one-year-old wife and mother who died of tuberculosis in 1894, soon after arriving in Alberta. Peterson and Woodward had in common their Mormon faith and status as immigrants in Canada. Nothing about their headstones displayed anything uniquely Mormon, such as a beehive or Angel Moroni. ${ }^{11}$
The monument memorializing Thomas $\mathrm{R}$. Leavitt [1834-1891] was more elaborate in that it included several standard Victorian symbols such as vines of ivy (representing immortality) running over two columns and an arch, and underneath a planter filled with calla lilies (symbolizing beauty, purity, and marriage).12 Leavitt's epitaph read: "A precious one from us has gone, A voice we loved is stilled, A place is vacant in our home, which never can be filled" (fig. 2). But, again, nothing specific to Mormonism. Noah Shurtleff's [18461892] simple marker laid flush with the lawn, presenting his full name, dates and locations of birth and death, and "Utah Pioneer 1851 - Canadian Pioneer 1888" (fig. 3). Like many of the early LDS settlers in Alberta, Shurtleff, at the age of four, travelled from lowa to Utah Territory with a Mormon migration company. The mention of Utah on his grave hinted at his faith that not all observers would understand.
Like the early Canadian LDS meetinghouses and tabernacles, memorials in their cemeteries also blended in as standard Christian graves. ${ }^{13}$ In the Stirling Cemetery, the blunt obelisk monument for Utah-born Austin G. Russell [1881-1900] included oak leaves, acorns, stars, his vita, an epitaph, and his family name (fig. 4). The oak leaves symbolized strength, and the acorns prosperity and spiritual growth. ${ }^{14} \mathrm{His}$ epitaph stated: "Blessed are the dead which die in the Lord," possibly inspired by Revelation in the New Testament. Chapter 14 of Revelation follows an account of great suffering, but, according to this prophecy, with the fall of Babylon comes better times for the faithful: "And I heard a voice from heaven saying unto me, Write, Blessed are the dead which die in the Lord from henceforth: Yea, saith the Spirit, that they may rest from their labours; and their works do follow them." 15 The blessed are those that "either die in the cause of Christ, or rather die in a state of vital union with Christ." ${ }^{16}$ This epitaph appeared on seven 
grave markers in the Cardston, Magrath, Raymond, and Stirling cemeteries (all in Alberta).

Another popular epitaph read "Asleep in Jesus." The headstone for Orin Leslie Kimball [1889-1901] expanded the quotation with "Asleep in Jesus, blessed sleep, From which none ever wake to weep." Inspiration may have come from the New Testament verse "For if we believe that Jesus died and rose again, even so them also which sleep in Jesus will God bring with him."17 The hymn published in 1832 by Margaret Mackey titled Asleep in Jesus could also have been influential. ${ }^{18}$ In his now famous sermon from 1844, LDS leader Joseph Smith [1805-1844] claimed: "We have reason to have the greatest hope and consolation for our dead of any people on the earth; for we have seen them walk worthily in our midst, and seen them sink asleep in the arms of Jesus; and those who have died in the faith are now in the celestial kingdom."19 Despite Smith's speech, "Asleep in Jesus" suited most Christian denominations and non-Mormons would have recognized the epitaph too.

During these early stages of settlement, Latter-day Saints faced numerous hardships such as harsh climate, difficult terrain, unpredictable crops, isolation and loneliness, and discrimination by non-Mormons. In southern Alberta, early LDS memorials, using generic Christian symbols, presented an image of faithful Christians, not so unlike their non-Mormon neighbours, who appeared to conform to external pressure.

\section{MORMON SYMBOLISM}

A new phase of Mormonism began with President Joseph F. Smith's Second Manifesto on April 6, 1904. The LDS Church officially prohibited post-Manifesto plural marriages (plural marriages occurring after 1890) and excommunicated disobedient members. The Church tried to disassociate from polygamy and re-brand "celestial marriage" in terms of longevity rather than multiplicity. ${ }^{20}$ John W. Taylor, a strong supporter of both the Canadian settlements and plural marriage, fell victim to these changes and was eventually excommunicated. In 1888, Taylor accompanied Charles Ora Card [1839-1906] to Ottawa with the goal of gaining permission to bring plural wives into Canada. The Canadian government denied this request and the visit alerted them to the Latterday Saints' intentions, which resulted in an amendment to the Criminal Code making polygamy an indictable offence in Canada. The LDS Church of the twentieth century did not want the dark cloud of polygamy to follow them any longer.

While distancing themselves from polygamy, Latter-day Saints did not want to separate themselves from their ancestors, whether or not they were connected by plural marriages, because the larger the extended family, "the greater its sense of achievement and, in a sense, of salvation."21 In the early twentieth century, one of the most popular carvings on Mormon grave markers in southern Alberta was the image of a gate. In her poem "Bury Me Quietly When I Die," famous Mormon poetess Eliza R. Snow [1804-1887] wrote: "What is death to the good, but an entrance gate / That is placed on the verge of a rich estate." 22 The image of the gate symbolized the faithful Latter-day Saints' entrance into the Celestial Kingdom. Mary Ann Meyers explained that, for Mormons, death was not devastating since "life on earth encompassed neither the beginning nor the end of human existence." 23 At the final judgment, when all have been resurrected, Latter-day Saints believed that each person will be assigned one of the three kingdoms of glory: the celestial, the terrestrial, or the telestial. Even within the Celestial Kingdom there are different degrees of glory and those members in the highest glory receive exaltation. One requirement of the highest degree is the priesthood who, religious studies scholar Douglas Davies explained, holds the keys that "unlock the gates of death and afford access to the several levels of heaven. Through ordination into this higher priesthood and through the temple rites accessible only to such priests, an identity is achieved that possesses the capacity to lead the believer through various post-mortem circumstances into the state of exaltation." ${ }^{24}$ The LDS Church taught holders of the Melchizedek Priesthood that they have the "power and authority to enter into the eternal worlds through the realm of death and in company with their spouses." 25 On numerous gravestones memorializing deceased Latter-day Saints, one finds the image of an open gate, the "gate of death" opened for the deceased with the keys of the priesthood.

In his chapter on Mormon cemeteries in the United States, geographer Richard $\mathrm{H}$. Jackson noted the occasional presence of gates on Mormon graves until 1870, which he interpreted as representing the entrance into paradise. ${ }^{26}$ Photographer and writer Douglas R. Keister agreed that gates symbolized passage from one realm to the next, or the Last Judgment. ${ }^{27}$ In his analysis of the historic cemeteries of Grand Rapids, Michigan, amateur historian Thomas R. Dilley observed an open gate on the 1901 gravestone of John Lodewyk as "an obvious end-of-life image suggesting departure and passage to another realm." ${ }^{28}$ In the Cardston Cemetery, the headstone of Fanny Elizabeth Caldwell [1880-1905] presented a wooden picketed gate swung open over a tiled floor and under a brick arch (fig. 5). Her epitaph, "She's gone to dwell with saints above, And rest in God's eternal love," is not exclusively Mormon, but it does present a message many LDS would understand. For example, the last verse of Abbie A. Bird's 


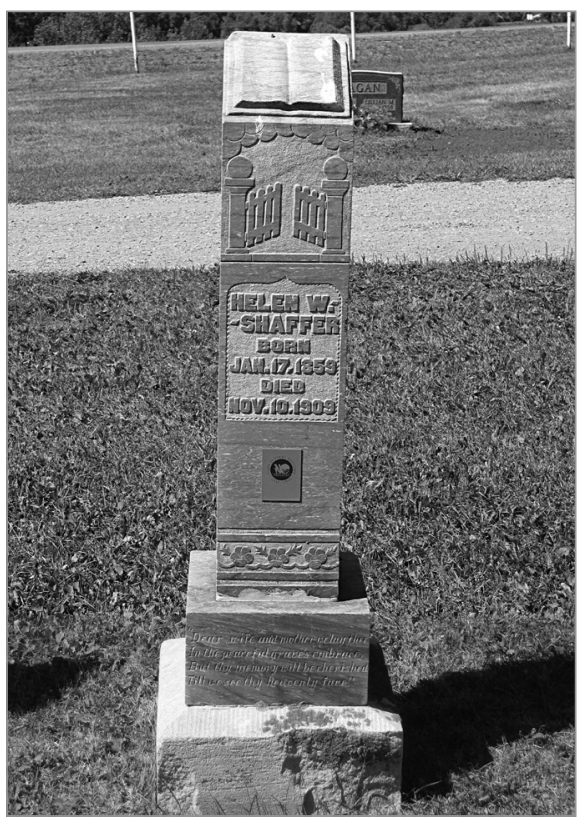

FIG. 6. HELEN SHAFFER'S OBELISK, MAGRATH CEMETERY.| BROOKE KATHLEEN BRASSARD.

poem "To The Memory of Those Who Are Gone," published in the LDS magazine The Young Woman's Journal, expressed: "That when we leave our earthly home / And in seeking friends above, / All will be ready there to greet, / And welcome us with love." 29

In the Magrath Cemetery, Helen Shaffer's [1859-1909] monument is an obelisk crowned with a carving of an open book, a common Christian symbol, which rested above an engraving of an opened gate (fig. 6). At the base, the epitaph, "Dear wife and mother we lay thee / In the peaceful grave's embrace. / But thy memory will be cherished / Till we see thy heavenly face," encouraged Mormons to remain faithful and active in order to reunite in the Celestial Kingdom.

Outsiders may not have understood the details of Mormon theology regarding the afterlife and, therefore, overlooked images of open gates as another standard Christian symbol. However, those with

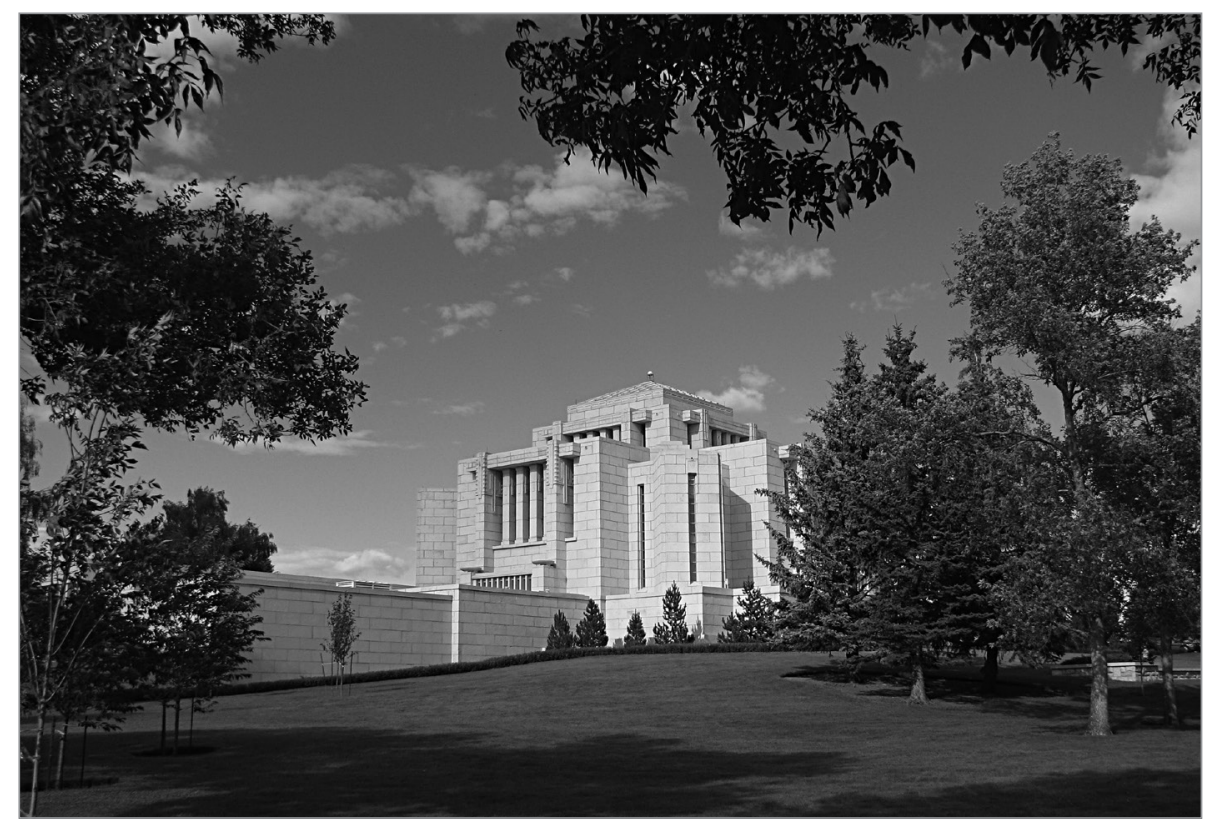

FIG. 7. CARDSTON ALBERTA TEMPLE, CARDSTON, ALBERTA. | BROOKE KATHLEEN BRASSARD.

connections to Mormonism and the faithful LDS would have knowledge of their specific beliefs regarding ancestors and family, the spiritual world and the three kingdoms, and the priesthood. This was not an outright challenge to mainstream society, but it was the start of a negotiation process that would eventually allow Latter-day Saints to express themselves with distinctly Mormon messages and images, creating firm borders differentiating themselves from non-Latter-day Saints.

\section{TEMPLE IMAGERY}

Over ten years after Jonathan Layne's prediction, in Salt Lake City, Church President Joseph F. Smith shared a prophecy concerning the global Church: "I foresee the necessity arising for other temples or places consecrated to the Lord for the performance of the ordinances of God's house, so that the people may have the benefit of the House of the Lord without having to travel hundreds of miles for that purpose." ${ }^{30}$ Smith officially announced the Church's plan to build a temple in Canada at the October 4, 1912, General Conference. $^{31}$

For their first temple outside of the United States, the Church decided to proceed with a new approach to temple design. They decided to hold a competition rather than commission the appointed Church architect, and invited fourteen architects to submit designs for consideration. On December 24, 1912, seven of those invited submitted their work to the Presiding Bishopric and thus began a new generation of temples in terms of not only appearance, but also purpose; temples became reserved for sacred ordinances only. ${ }^{32}$ The Presiding Bishopric displayed the anonymous competition entries at the Bishop's building until they selected the winning design. Church authorities announced that Harold W. Burton and Hyrum Pope's entry had been chosen and they would be the architects for the Cardston temple (fig. 7). 


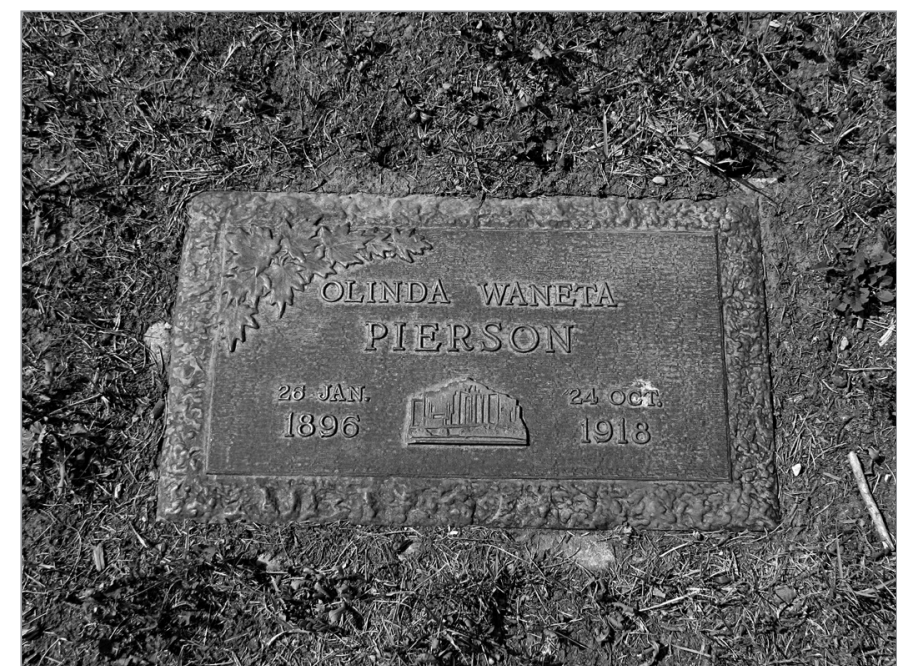

FIG. 8. OLINDA AND OLA PIERSON'S GRAVE MARKER, STIRLING CEMETERY.| BROOKE KATHLEEN BRASSARD.

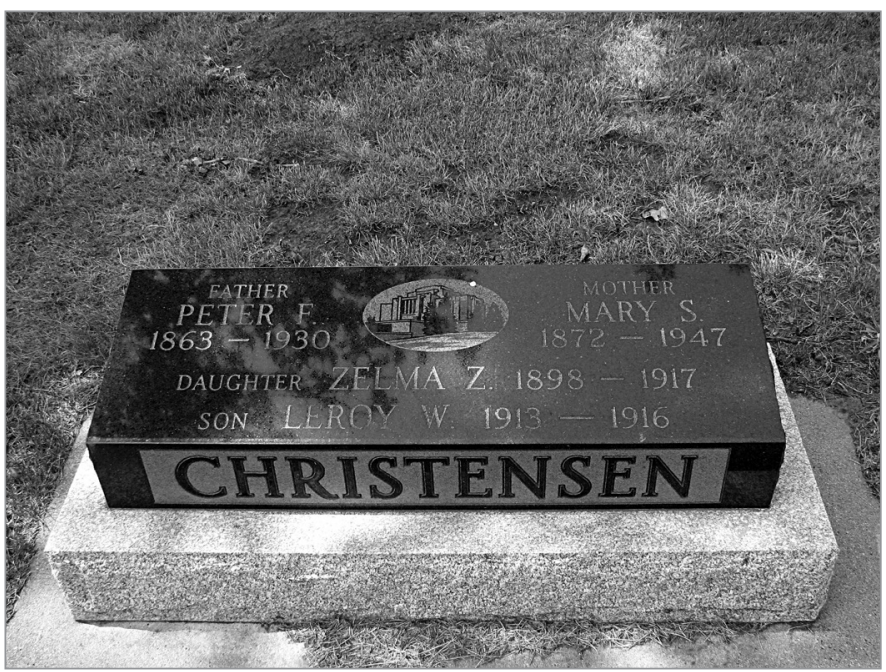

FIG. 9. CHRISTENSEN FAMILY MARKER, STIRLING CEMETERY. | BROOKE KATHLEEN BRASSARD.
Pope and Burton's design stood apart from the Utah temples. Even journalists in Salt Lake City close to Church headquarters were confused by the architectural style of the first Canadian temple, stating: "The architecture of the proposed building cannot be identified exactly with any historically accepted style. The aim of the architects was to conform to the peculiar requirements of such a building rather than to imitate any style." ${ }^{33}$ A Raymond resident agreed, writing for Canadian Magazine in 1913: "The architecture will not correspond to that of any temple erected by the church in Utah. The authorities seek utility in the Canadian building rather than adherence to any type of revealed plan." ${ }^{34}$ The architects allowed the purpose of the building to drive their design and let typical ecclesiastical styles take a back seat. The modern architects of the time, such as Louis Sullivan [1856-1924] and Frank Lloyd Wright [1867-1959], would have described this as "form follows function." The architects designed the temple according to its function, which all LDS temples were made to serve. There was no longer a need for an assembly hall because now the temple was reserved for sacred ordinances. The exterior of the Cardston Alberta Temple differed from the Gothic Utah temples, but the interior rooms and baptismal fonts remained similar and served the same functions. However, at that time, Mormonism began to act the opposite in terms of its relationship with other Christianities. To the outside they appeared the same, but inside they remained unique. For example, the Church gave up polygamy and officially punished defiant members who continued to practice, but then began to re-emphasize the importance of family by initiating the tradition of Family Home Evenings. ${ }^{35}$

Frank Steele, writing for the LDS publication Juvenile Instructor, determined that the Cardston Alberta Temple "convinced Canada that the Latter-day Saints are an intensely earnest people, that they are established permanently, [and] that they are substantial citizens." ${ }^{36}$

The temple eliminated one reason for Latter-day Saints to return to the United States. The temple did not visually assimilate into the small, rural town, but it fit into Canadian Mormons' needs. Now that they had a temple in Canada, new missionaries, young couples, and families did not have to travel south of the border to receive sacred ordinances.

Additionally, V.A. Wood interpreted the temple's meanings further:

For the members of the Mormon church the dedication of the Alberta Temple was a time of great anticipation, celebration and spiritual renewal. It was also the culmination of the hopes, dreams and sacrifices made by the Mormon pioneers who came to Alberta prior to 1923. To the Church members in Alberta the Temple stood in its place of prominence as a symbol of their sacrifice, of the Lords [sic] acceptance of their labours and of the unity and strength of the members of the area.37

The Cardston Alberta Temple symbolized success. The Latter-day Saints had come a long way since setting up camp along Lee's Creek in 1887.

Images of the Cardston Alberta Temple began appearing in cemeteries even before the LDS Church completed construction. 


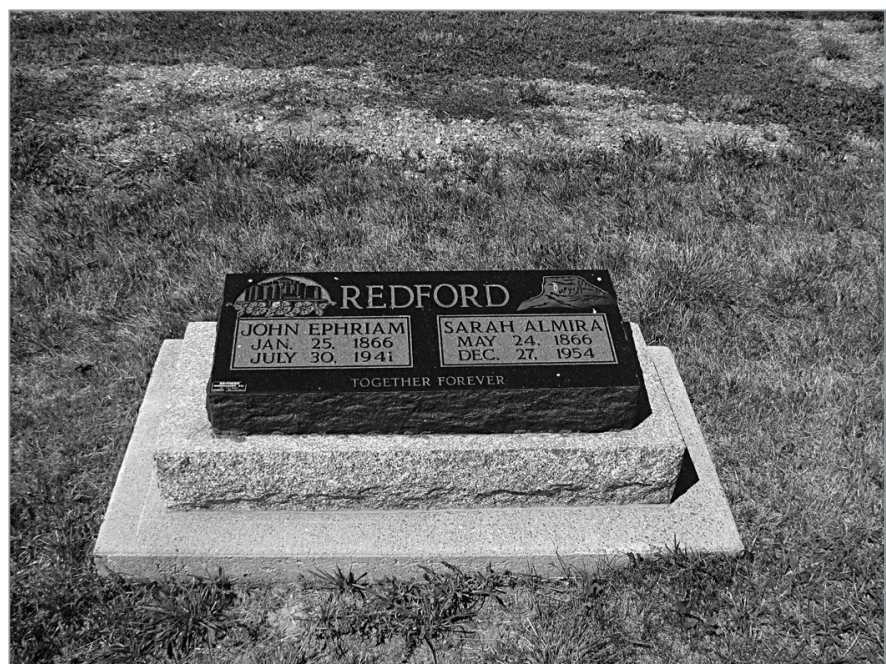

FIG. 10. REDFORD'S GRAVE MARKER, LEAVITT CEMETERY. | BRooke KATHLEEN BRASSARD.

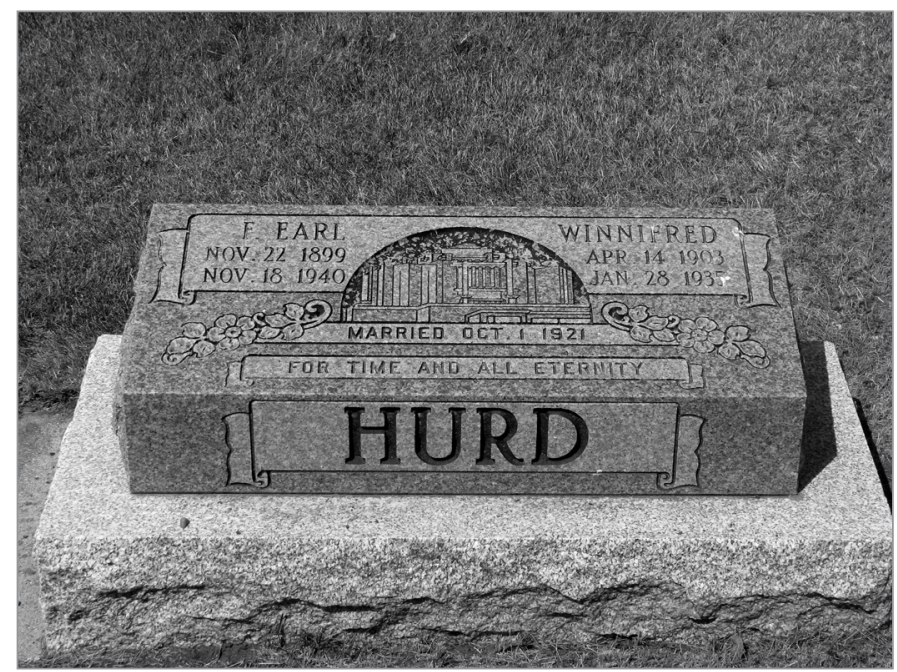

FIG. 11. EARL AND WINNIFRED HURD'S GRAVE MARKER, CARDSTON CEMETERY. | BRooKE KATHLEEN BRASSARD.
In the Stirling Cemetery, laying flat to the ground, the grave markers of daughter Olinda Pierson [1896-1918] and father Ola Pierson [1848-1922] pictured maple leaves and the Cardston Alberta Temple cut into bronze plaques (fig. 8). Although Ola died at seventy-three years old, the flu epidemic of 1918 ended the life of his daughter Olinda early, at the age of twenty-two. The temple on their grave markers symbolized "the belief that there is a way to achieve victory over death, not just for the individual, but for the family unit, both nuclear and extended." ${ }^{38}$ In his guide to cemetery symbolism and iconography, Keister included the Mormon temple in his extensive list of symbols and wrote that it represented one thing: Mormonism. ${ }^{39}$

The image of a temple, wrote Edison, "symbolizes the place and the means through which the goal of eternal marriage and family unity is achieved."40 Grave markers displaying a Mormon temple communicated "basic Mormon beliefs of eternal progression, marriage for time and eternity, and the sealing together of families." ${ }^{41}$ The rectangular slab marker for the Christensen family listed the father Peter F. [1863-1930], the mother Mary S. [1872-1947], daughter Zelma Z. [1898-1917], and son Leroy W. [1913-1916]. In between the parents and above the children was an etching of the Cardston Alberta Temple and not the Manti Temple, where Peter and Mary were probably married since they wed in Manti in 1891 (fig. 9). Another couple who were not married in the Cardston Alberta Temple were John Redford [18661941] and Sarah Redford [1866-1954]. Despite marrying in 1886 in Logan, Utah, and probably being sealed in the Logan Temple, the Redfords's gravestone in the Leavitt Cemetery not only depicted the Cardston Alberta Temple, but also displayed Chief Mountain, a significant feature of the landscape in their adopted home of southern Alberta (fig. 10). This is perhaps not surprising when considering that four of their nine children were born in Alberta, and that they spent the rest of their lives there after immigrating between 1895 and 1899.

In the Cardston Cemetery, the granite marker for F. Earl Hurd [1899-1940] and
Winnifred Hurd [1903-1935] displayed the Cardston Alberta Temple, their marriage date of October 1, 1921, and the epitaph "For time and all eternity" (fig. 11). That epitaph, like the temple, was distinctly Mormon. For Latter-day Saints, marriage in the temple involved the ceremony of sealing, which joined the couple together "for time and all eternity." This was the LDS covenant of marriage. ${ }^{42}$

In her study of Mormon graves in Utah, what Carol Edison labelled as "temple gravestones," she defined as "a folk expression of organizational affiliation and religious belief. [Temple gravestones] speak not only to outsiders as a statement of Mormon religious identity, but also to insiders as a reminder and visual reinforcement of the essence of Mormon belief."43 The LDS temple in Cardston symbolized the permanence of Mormonism in Canada and the presence of the temple on grave markers demonstrated a way the LDS announced their religious affiliation, no longer favouring standard Christian icons, but embracing the uniquely Mormon symbol of the temple. 


\section{CANADIAN AND MORMON}

The six cemeteries in southern Alberta discussed here provided not only a look at how Latter-day Saints commemorated their deceased loved ones, the images and words they chose for example, but also how that commemoration changed over time. The longer they stayed in Canada and the more "Canadian" they became, the easier it was to express their Mormon identity. The image of LDS temples on gravestones in Canadian cemeteries demonstrated an established confidence in their new home. By the time the temple appeared in Canadian cemeteries, World War I was coming to an end, but many LDS had joined Canadian Armed Forces and served their country, proving they were just as loyal citizens as their nonLDS neighbours. With this confidence in their reformed status as loyal Canadians, the LDS reached a stage of integration into Canadian society that allowed them to risk their level of acceptance by publicly displaying Mormon images such as the Cardston Alberta Temple. They embraced their integration into Canadian society while at the same time reinforcing boundaries that maintained their distinctiveness as Latter-day Saints.

\section{NOTES}

1. Wood, V.A., 1989, The Alberta Temple: Centre and Symbol of Faith, Calgary, Detselig Enterprises Ltd.; Cowan, Richard O., 2000, "The Alberta Temple: Seventy-five Years of Service," in Dennis A. Wright, Robert C. Freeman, Andrew H. Hedges, and Matthew O. Richardson (eds.), Regional Studies in Latterday Saint Church History Western Canada, Provo, Department of Church History and Doctrine, Brigham Young University, p. 239.

2. Wood, p. 27; Cowan, p. 240.

3. Fife, Austin and Alta Fife, 1980, "Gravestone Imagery," in Hal Cannon (ed.), Utah Folk Art: A Catalog of Material Culture, Provo, Brigham Young University Press, p. 138.
4. Edison, Carol, 1989, "Mormon Gravestones: A Folk Expression of Identity and Belief," Dialogue: A Journal of Mormon Thought, vol. 22, no. 4, p. 89. See also: Millar, Nancy, 1997, Once Upon a Tomb: Stories from Canadian Graveyards, Calgary, Fifth House Ltd. Millar said that graveyards are "microcosms of our communities." Richard H. Jackson agreed that "each cemetery is an ever changing volume that records the history, values, and dreams of a people and place." See Jackson, Richard H., 1999, "Mormon Cemeteries: History in Stone," in Ronald W. Walker and Doris R. Dant (eds.), Nearly Everything Imaginable: The Everyday Life of Utah's Mormon Pioneers, Provo, Brigham Young University Press, p. 405.

5. Martens, Steve C. and Nancy Volkman, 2004, "Cemeteries," in David J. Wishart (ed.), The Encyclopedia of the Great Plains, Lincoln and London, University of Nebraska Press, p. 70.

6. Brown, John Gary, 2004, "Grave Markers," in David J. Wishart (ed.), The Encyclopedia of the Great Plains, Lincoln and London, University of Nebraska Press, p. 303

7. Wright, Elizabethada A., 2005, "Rhetorical Spaces in Memorial Places: The Cemetery as a Rhetorical Memory Place/Space," Rhetoric Society Quarterly, vol. 35, no. 4, p. 51. Wright continued: "If one sees cemeteries as a rhetorical space, then there are thousands upon thousands of voices clamoring to be heard, a cacophony of remembrances are calling out" (p. 60).

8. Brassard, Brooke Kathleen, 2018, Thirsty Land into Springs of Water: Negotiating a Place in Canada as Latter-day Saints, 1887-1947, Ph.D. dissertation in religious studies, University of Waterloo.

9. Jackson, "Mormon Cemeteries," p. 408 Keister, Douglas, 2004, Stories in Stone: $A$ Field Guide to Cemetery Symbolism and Iconography, Layton, Gibbs Smith; Davis, Ren and Helen Davis, 2012, Atlanta's Oakland Cemetery: An Illustrated History and Guide, Athens and London, The Historic Oakland Foundation and the University of Georgia Press.

10. The epitaph came from the second verse of a hymn written by Isaac Watts [1674-1748]: "A Funeral Ode at the Interment of the Body, Supposed to be Sung by the Mourners" "No pain, no grief, no anxious fear / Invade thy bounds; no mortal woes / Can reach the lovely sleeper here." Like many Christian denominations of the time, Mormons adopted these lyrics during their time in Nauvoo, Illinois, in 1841. Chism, Shane J. (ed.), 2011, A
Selection of Early Mormon Hymnbooks, 18321872: Hymn Books and Broadsides from the First 40 Years of the Church of Jesus Christ of Latter-day Saints, Tucson, n.p. The hymn appeared as "Hymn 223" in 1841, A Collection of Sacred Hymns, for the Church of Jesus Christ of Latter-Day Saints, Nauvoo, E. Robinson.

11. Early LDS leaders selected the symbol of the beehive because it represented industry, perseverance, community, and sweet rewards for hard work. The beehive appeared on numerous LDS-related items such as Churchrelated logos and the emblem for the state of Utah. See: Oman, Richard G., 1992, "Beehive Symbol," and Romney, Joseph B., 1992, "Moroni, Angel," both in Daniel H. Ludlow (ed.), Encyclopedia of Mormonism, New York, Macmillan, p. 99 and 953 respectively.

12. American Monument Association, 1947, Memorial Symbolism, Epitaphs and Design Types, Boston, American Monument Association; Filey, Mike, 1999, Mount Pleasant Cemetery: An Illustrated Guide, Toronto, Dundurn Press; Keister, Stories in Stone, p. 57; Davis and Davis, p. 188-189.

13. The Latter-day Saints built several places of worship in southern Alberta that resembled other churches in the area specifically, churches located in Lethbridge and Fort Macleod. For example, the Cardston meetinghouse (1888), Cardston Assembly Hall (1893), Raymond meetinghouse (1903), and Alberta Stake Tabernacle (1904-1912). The meetinghouses and assembly hall followed earlier models of the New England variety and the tabernacle fell under a more eclectic style of Neo-Gothic.

14. American Monument Association, Memorial Symbolism, p. 21; Keister, Stories in Stone, p. 61; Dilley, Thomas R., 2014, The Art of Memory: Historic Cemeteries of Grand Rapids, Michigan, Detroit, Wayne State University Press.

15. Revelation 14:13, KJV.

16. Henry, Matthew, 1850, A Commentary on the Holy Bible with Practical Remarks and Observations, Volume IX, New York and London, Funk \& Wagnalls Company.

17. 1 Thessalonins 4:14, KJV. Another possible verse: "But now is Christ risen from the dead, and become the firstfruits of them that slept" (1 Cor. 15:20).

18. Mackay, Margaret, 1880, "Asleep in Jesus," in Philip Schaff and Arthur Gilman (eds.), A Library of Poetry for Sunday Reading, New York, Dodd, Mead and Company, p. 683. 
19. The King Follett Sermon, April 7, 1844, [https:// www.lds.org/ensign/1971/05/the-king-follettsermon?lang=eng], accessed May 31, 2017.

20. Flake, Kathleen, 2004, The Politics of American Religious Identity: The Seating of Senator Reed Smoot, Mormon Apostle, Chapel Hill, University of North Carolina Press.

21. Davies, Douglas J., 1997, Death, Ritual and Belief: The Rhetoric of Funerary Rites, London and Washington, Cassell; Properzi, Mauro, 2015, Mormonism and the Emotions: An Analysis of LDS Scriptural Texts, Madison and Teaneck, Fairleigh Dickinson University Press.

22. Snow, Eliza R., 1881, "Bury Me Quietly When I Die," The Woman's Exponent, vol. 10, no. 13, p. 97.

23. Meyers, Mary Ann, 1975, "Gates Ajar: Death in Mormon Thought and Practice," in David E. Stannard (ed.), Death in America, Philadelphia, University of Pennsylvania Press, p. 114.

24. Davies, Douglas J., 2000, The Mormon Culture of Salvation, Aldershot, Ashgate Publishing.

25. Id., p. 86.

26. Jackson, "Mormon Cemeteries," p. 408.

27. Keister, Stories in Stone, p. 116.

28. Dilley, The Art of Memory, p. 163.

29. Bird, Abbie A., 1896, "To the Memory of Those Who Are Gone," The Young Woman's Journal, vol. 8 , no. 1 , p. 1.

30. Wood, The Alberta Temple, p. 27-28. Cowan, "The Alberta Temple," p. 239.

31. Cowan, "The Alberta Temple," p. 240. Alberta Stake President Edward J. Wood recorded: "and to the surprise of us all he announced that the Church would build a Temple in Canada." See Tagg, Melvin S., 1959, "The Life of Edward James Wood," master's thesis, College of Religious Instruction, Brigham Young University, p. 92.

32. Cowan, Richard O., 1997, Temples to Dot the Earth, Springville, Cedar Fort.

33. 1913, "Approved Design for Temple in Alberta Province," Deseret Semi-weekly News, p. 5.

34. Tait, W. McD., 1913, "The Mormon Temple in Canada," Canadian Magazine, vol. 42, p. 488.

35. In April 1915, the First Presidency sent a letter to Church leaders advising them to inaugurate a "Home Evening" where fathers and mothers were to gather their children in the home and teach them valuable lessons. LDS families came together at least one night a week to pray, sing hymns, read scripture, discuss family topics, and receive instruction on the principles of the Gospel. Over a hundred years later, Church members continue this tradition. The practice of Family Home Evening ensured that LDS families "would not suffer the social fragmentation that was becoming common in postwar society. For them the family, rather than the individual, was the basic unit of society." See Allitt, Patrick, 2003, Religion in America Since 1945: A History, New York, Columbia University Press.

36. Steele, Frank C., 1923, "The Cardston Temple," Juvenile Instructor, vol. 58, no. 9, p. 439.

37. Wood, The Alberta Temple, p. 73.

38. Edison, "Mormon Gravestones," p. 92.

39. Keister, Stories in Stone, p. 121.

40. Edison, "Mormon Gravestones," p. 92.

41. Id., p. 91.

42. McDannell, Colleen and Bernhard Lang, 2001, "Modern Heaven . . a and a Theology," in Eric Alden Eliason (ed.), Mormons and Mormonism: An Introduction to an American World Religion, Urbana and Chicago, University of Illinois Press, p 137-146, at p. 142.

43. Edison, "Mormon Gravestones," p. 92. 